Global Perspectives on the Health of Seeds and Plant Propagation Material 


\section{Plant Pathology in the 21st Century}

More information about this series at

http://www.springer.com/series/8169 
Maria Lodovica Gullino - Gary Munkvold Editors

\section{Global Perspectives on the Health of Seeds and Plant Propagation Material}

Volume 6

望 Springer 


\section{Editors}

Maria Lodovica Gullino

AGROINNOVA

Università degli Studi di Torino

Grugliasco

Torino

Italy
Gary Munkvold

Plant Pathology and Microbiology

Iowa State University

Ames

Iowa

USA

ISBN 978-94-017-9388-9

ISBN 978-94-017-9389-6 (eBook)

DOI 10.1007/978-94-017-9389-6

Springer Dordrecht Heidelberg New York London

Library of Congress Control Number: 2014952658

(C) Springer Science+Business Media Dordrecht 2014

This work is subject to copyright. All rights are reserved by the Publisher, whether the whole or part of the material is concerned, specifically the rights of translation, reprinting, reuse of illustrations, recitation, broadcasting, reproduction on microfilms or in any other physical way, and transmission or information storage and retrieval, electronic adaptation, computer software, or by similar or dissimilar methodology now known or hereafter developed. Exempted from this legal reservation are brief excerpts in connection with reviews or scholarly analysis or material supplied specifically for the purpose of being entered and executed on a computer system, for exclusive use by the purchaser of the work. Duplication of this publication or parts thereof is permitted only under the provisions of the Copyright Law of the Publisher's location, in its current version, and permission for use must always be obtained from Springer. Permissions for use may be obtained through RightsLink at the Copyright Clearance Center. Violations are liable to prosecution under the respective Copyright Law.

The use of general descriptive names, registered names, trademarks, service marks, etc. in this publication does not imply, even in the absence of a specific statement, that such names are exempt from the relevant protective laws and regulations and therefore free for general use.

While the advice and information in this book are believed to be true and accurate at the date of publication, neither the authors nor the editors nor the publisher can accept any legal responsibility for any errors or omissions that may be made. The publisher makes no warranty, express or implied, with respect to the material contained herein.

Printed on acid-free paper

Springer is part of Springer Science+Business Media (www.springer.com) 


\section{Foreword}

This volume continues the series of books on "Plant Pathology in the 21st Century", which started in 2010, in cooperation with the International Society for Plant Pathology and contains the papers given at the 10th International Congress of Plant Pathology (ICPP 2013) held in Beijing, August 25-30, 2013 concerning seed health.

The use of healthy seeds and propagation material is a prerequisite in any cropping systems, because it permits to strongly reduce the further adoption of other disease management strategies in the field during the cultivation.

Many pathogens are transmitted throughout infected seeds and propagation material. The fact that propagation material production is very much concentrated in few establishments, favors the quick spread of new diseases throughout seed commercialization. This phenomenon is very much accelerated in a globalized system.

The book covers case studies of contamination, aspects of detection and diagnosis as well as disease management strategies, with special emphasis towards seed treatments with unconventional products.

We believe that, besides representing a written testimony of ICPP 2013, this book will be useful for all plant pathologists as well as students in advanced courses.

We wish to thank all the colleagues who accepted to be part of this book, Zuzana Bernhart and her group at Springer for their continuous support and Laura Castellani for her skilfull technical assistance.

The Editors 



\section{Contents}

\section{Part I General Aspects}

1 Seed Transmission in the Potyviridae .................. 3 Heather E. Simmons and Gary P. Munkvold

2 Global Standards in Seed Health Testing . . . . . . . . . . . . . . 17 Theresa A.S. Aveling

3 Seed-Borne Pests and Phytosanitary Issues: the Role of EPPO . . . . 29 Françoise Petter, Muriel Suffert, Madeleine McMullen, Daminen Griessinger, and Anne-Sophie Roy

4 Seed-Borne Fungal Pathogens of Leafy Vegetable Crops . . . . . . . . . M. Lodovica Gullino, Giovanna Gilardi, and Angelo Garibaldi

\section{Part II Detection}

5 Technical Challenges for Specific, Sensitive Detection of Seed-Borne Bacterial Pathogens . . . . . . . . . . . . . . . . . . .

Norman W. Schaad, Carmen N. Mortensen, Jianqiang Li, Jianjun Feng, Laixin Luo, Angelo Mazzaglia, and Giorgio M. Balestra

6 Improved Detection and Monitoring of Seed-Borne Fungal Plant Pathogens in Europe . . . . . . . . . . . . . . . . . . . . . Giovanni Vannacci, Sabrina Sarrocco, and Angelo Porta-Puglia

\section{Part III Seed Treatments}

7 Benefits of Chemical Seed Treatments on Crop Yield and Quality . . . Gary P. Munkvold, Clifford Watrin, Monika Scheller, Ronald Zeun, and Gilberto Olaya 
8 Non-chemical Seed Treatment in the Control of Seed-Borne

Pathogens . . . . . . . . . . . . . . . . . . . . . . . 105

Eckhard Koch and Steven J. Roberts

9 Chemical and Non Chemical Seed Dressing for Leafy Vegetable Crops .................................. 125

M. Lodovica Gullino, Giovanna Gilardi, and Angelo Garibaldi 


\section{Contributors}

Theresa A. S. Aveling University of Pretoria, Pretoria, South Africa

Giorgio M. Balestra Department of Agriculture, Forestry, Nature and Energy, University of Tuscia, Tuscia, Italy

Jianjun Feng Animal \& Plant Quarantine Technology Center, Shenzhen, People's Republic of China

Angelo Garibaldi AGROINNOVA, University of Torino, Grugliasco, Italy

Giovanna Gilardi AGROINNOVA, University of Torino, Grugliasco, Italy

Daminen Griessinger European and Mediterranean Plant Protection Organization, Paris, France

M. Lodovica Gullino AGROINNOVA, DISAFA, University of Torino, Grugliasco, Italy

Eckhard Koch Julius Kühn-Institute, Dresden, Germany

Jianqiang Li Department of Plant Pathology, China Agricultural University, Beijing, People's Republic of China

Laixin Luo Department of Plant Pathology, China Agricultural University, Beijing, People's Republic of China

Angelo Mazzaglia Department of Agriculture, Forestry, Nature and Energy, University of Tuscia, Tuscia, Italy

Madeleine McMullen European and Mediterranean Plant Protection Organization, Paris, France

Carmen N. Mortensen Danish Seed Health Centre, Department of Plant and Environmental Sciences, University of Copenhagen, Copenhagen, Denmark

Gary P. Munkvold Seed Science Center, Iowa State University, Ames, IA, USA

Gilberto Olaya Syngenta Crop Protection, Vero Beach, FL, USA 
Françoise Petter European and Mediterranean Plant Protection Organization (EPPO), Paris, France

Angelo Porta-Puglia Istituto Sperimentale per la Patologia Vegetale (presently CRA-PAV), Rome, Italy

Steven J. Roberts Plant Health Solutions Ltd, Warwick, UK

Anne-Sophie Roy European and Mediterranean Plant Protection Organization, Paris, France

Sabrina Sarrocco Dipartimento di Scienze Agrarie, Alimentari e Agro-ambientali, Università di Pisa, Pisa, Italy

Norman W. Schaad USDA, ARS, Foreign Disease Weed Science-RU, Ft. Detrick, MD, USA

Thousand Oaks, CA, USA

Monika Scheller Syngenta Crop Protection, Basel, Switzerland

Heather E. Simmons Syngenta Crop Protection, Basel, Switzerland

Muriel Suffert European and Mediterranean Plant Protection Organization, Paris, France

Giovanni Vannacci Dipartimento di Scienze Agrarie, Alimentari e Agro-ambientali, Università di Pisa, Pisa, Italy

Clifford Watrin Syngenta Crop Protection AG, Basel, Switzerland

Ronald Zeun Syngenta Crop Protection, Stein, Switzerland 